\title{
Music education - a personal matter? Examining the current discourses of music education in Sweden
}

\section{Eva Georgii-Hemming and Maria Westvall}

Örebro University, School of Music, Theatre and Art, SE-701 82 Örebro, Sweden

eva.georgii-hemming@oru.se

maria.westvall@oru.se

The embedding of informal practices in music education in school relates to significant issues concerning students' engagement, participation, inclusion and the role of the teacher. This article addresses these issues by presenting and discussing current music education in compulsory comprehensive schooling in Sweden. It does so by drawing upon music pedagogical research, music education studies conducted during the last 10 years and national evaluations. Examples of practice from upper secondary schools are also used to clarify and illustrate the issues under consideration. It has been said that Swedish music education has gone from 'School Music' to 'Music in School'. This development has been characterised by greater influence of students on curriculum content resulting in increased use of popular music, and, consequently, teaching strategies acquired from informal music playing contexts. The curriculum states that the core of the subject is practical music playing, through which personal development can occur - both musically and socially. Music education in several other countries is developing a more practical approach, and the role of popular music in schools, and what is sometimes called informal learning, is featured in international music pedagogy debates. This article considers the musical, pedagogical and democratic consequences of this pedagogy from a Swedish perspective. As a result of a sharp focus on personal social development and individual students' musical interests, music education in Sweden has become relatively limited in terms of repertoire, content and teaching methods. Recent evaluations and studies also demonstrate that music education lacks direction, and is short of creative engagement with music. The role of the teacher is unclear and sometimes lacks validity in a practical music education situation. Viewed from an international perspective, the kind of music education that has developed in Sweden is unique. Thus, when the possibilities and limitations of music education in Sweden are discussed, it has the potential to be of interest to international music education research.

\section{Introduction}

In a number of countries there has been a trend over the last 10 years to develop pedagogical strategies for the classroom informed by musical learning and engagement in informal contexts usually beyond the school. Informal pedagogical strategies have been regarded as a tool for students' increased motivation, participation and inclusion with music in 
schools. However, experiences from music education in Sweden, stretching back over a considerable number of years, suggests caution in making such assumptions.

One objective with an informal pedagogical approach is to emphasise the individual student's personal experiences and his/her freedom to choose. Although Swedish music teachers' general intention is to take account of the students' 'own' music, studies have shown that this purpose is not fulfilled since not all students' musical life worlds are represented. Swedish students generally enjoy music in schools, but at the same time they find the subject to be old-fashioned and lacking in range of genres (Skolverket [Swedish National Agency for Education] 2004a, 2004b). Accordingly, not all students feel their musical preferences are included in music education.

Studies concerning music education in Sweden also reveal that there is a focus on musical activities, skills and reproduction, rather than on the development of artistic and creative competencies by means of activities such as composition and improvisation (Georgii-Hemming, 2005; Georgii-Hemming \& Westvall, 2010).

In addition, recent studies demonstrate that music teaching often lacks direction (Georgii-Hemming, 2005; Georgii-Hemming \& Westvall, 2010). It could be debated whether this is due to a sharp focus on individual students' interests and personal development, supplemented with an openly formulated curriculum. This raises questions concerning the role of the teacher in learning processes.

Although educational researchers and national evaluators of education agree that a variety of students' personal experiences should be included in the school context, questions are raised concerning whether music education has become too limited in relation to repertoire, content and teaching methods. For that reason, the main issue in the ongoing debate on a national level is whether the objectives of participation, inclusion and democratic values are achieved through the current Swedish approach to music education (Georgii-Hemming \& Westvall, 2010).

\section{Music education in Sweden: A brief history}

Over the past 40 years the music curriculum in Sweden has undergone major changes. These have been described as a transition from 'School Music' to 'Music in School' (Stålhammar, 1995). This transition represents a shift from music as being a distinctive school subject towards a subject with a significant inclusion of students' own musical experiences and preferences from outside of school. The shift does not exclusively concern music education, as there is an increased emphasis on democratic values and students' participation in the general curriculum.

Music as a school subject achieved its subject status in 1955. Prior to this the subject was called singing. Singing was dominated by hymns and aimed at strengthening church singing, morale and national identity (Stålhammar, 1995; Sandberg, 2006). In the 1960s, a 9-year compulsory comprehensive school education was introduced for all children. Previously, in the 1946 School Commission's report (SOU, 1948:27), which laid the foundations for this reform, the role of education to support democratic values was emphasised. Advocating a progressive interpretation of 'citizenship education', it was said that school had to pay attention to children's participation and inclusion. At the same time the School Commission claimed that democratic teaching should have an objective and 
scientific basis. Therefore the primary purpose of music education according to the first curriculum was on aesthetic education with a starting point in Western Classical music. The subject focused on sight-reading music, singing in harmony and knowledge of Western music history (Lgr 62; Stålhammar, 1995).

As a result of the emergence of popular music and youth culture during the 1960s the curriculum was revised in 1969. The new curriculum took the first step away from 'traditional' music education and music teachers were encouraged to use 'teenage music' (Lgr 69; Sandberg, 2006). The repertoire was further widened in the subsequent national curriculum ( $\operatorname{Lgr} 80$ ). This curriculum was designed around three main themes; To play together, To create music, and Music in society and the world. The latest curriculum was introduced in 1994 and revised in 2000 (Lpo 94; Kursplan, 2000). In this curriculum, music as a means of creating identity and for personal development is emphasised, and the core of the subject is defined as the act of playing together.

Since the 1990s, a decentralised education system has been introduced. This means that teachers can teach in a variety of ways based on centrally defined criteria. Thus, there can be a great deal of variation in music education between schools, resulting from resources in individual schools, individual teachers' knowledge or prioritisations (Forsberg, 2000; Englund, 2005).

\section{Music education in Sweden today - content and design of lessons}

Large group singing and playing in pop- and rock bands dominate Swedish music education according to both research studies (Georgii-Hemming, 2005) and the national evaluation from 2003 (Skolverket, 2004a, 2004b, 2005). The musical material is derived from pop and rock genres and teachers are striving for as much authenticity as possible in their teaching. One can never escape the fact that a school is an institution with some, more or less, defined frameworks and conditions. Despite this, it appears that music teachers in Sweden are striving for an experience of music and playing music which is as close to the musical practice outside of school as possible.

Usually, the students are relatively free to choose which songs they wish to play and with what students to play or 'form a band'. The process resembles as far as possible the methods of pop- and rock bands; basically listen, test and play. Students have the opportunity to make their own musical decisions, cooperate with one another and the music learning is mainly peer-directed. Singing and playing can be said to be the content, the method as well as the objectives (Lilliestam, 1995, 2001; Georgii-Hemming, 2005).

The teaching reflects the aims of the curriculum, which emphasises practical skills, singing and playing (Kursplan, 2000). The importance of teaching and learning being rooted in the individual student's needs and motivation is reinforced in openly formulated documents that do not regulate teaching strategies and curriculum content in detail. The idea is that the teacher should, together with students and according to local conditions, plan and implement the teaching and learning that goes on in the classroom. Recent research studies reveal that implementation of music education varies greatly between individual schools. Furthermore, there are few music teachers that use the texts available in different guidance documents, which are the starting point for teaching. Instead, they design 'their own curriculum' based upon openness towards students' leisure music and the 
individual competencies of the teachers (Ericsson, 2001; Skolverket, 2007, p. 34; GeorgiiHemming \& Westvall, 2010).

\section{Music education in Sweden today - music teachers'goals and ambitions}

When music teachers are asked what their teaching should give to the student, ideas of personal and social development dominate, rather than musical communication and experience. The teachers want musically engaged students who extend this interest beyond the scope of an educational institution and apply it for individual or cultural needs (Skolverket, 2004a, 2004b; Georgii-Hemming, 2005, 2006). The function and use of music is playing, a skilled process with its foundation built upon practice (Varkøy, 2001; Elliott, 2005).

Music as a phenomenon is not focused on, and music is certainly not seen as an autonomous object. However, the meaning of music is perceived as a unique source for personal and social development. Therefore every student must be respected, learn to cooperate, be given opportunities to find their identity and become a fulfilled human being with self-confidence. They must also be made aware of - and take responsibility for - what he or she learns, discover their own abilities and the potential value of aesthetic knowledge. Music is the uniting link between these ambitions. Music and human experiences belong together; through positive musical experiences human beings can feel joy and solidarity, develop self-esteem and discover that different forms of knowledge have a value (GeorgiiHemming, 2005; Skolverket, 2007).

\section{Music education in Sweden today - what is not being prioritised?}

It appears that singing and playing mainly pop- and rock music dominates music teaching in Sweden. Western Classical music, jazz, folk music or music from other cultures is only marginally integrated into the teaching. The selections of styles within pop- and rock genres are also limited.

Popular music is today a large and global musical field that can contain both old and new music, from traditional bands to music produced through different types of digital technology. Regardless of whether students or teachers choose the repertoire, it often involves music that students know well. Despite the intentions of the curriculum, few teachers actively work towards teaching in a way that reflects several cultural and musical fields - irrespective of whether they work in a school in a larger or smaller city or in a school with or without ethnic diversity (Kursplan, 2000). A new form of school music based on easy-to-play pop- and rock songs seems to have emerged. This includes both current hits (e.g. I'm Yours with Jason Mraz), traditional songs (e.g. Tom Dooley) and also songs by groups such as Creedence Clearwater Revival, Kiss and Oasis (Karlsson \& Karlsson, 2009).

Even though some music teachers utilise computers in their classes (e.g. sequencer programmes) and allow students to mix music or work with DJ equipment, these instances are mainly an exception. Particular teaching strategies for creating music with the help of digital media are rare, as are discussions about the role of music in advertisements, films, dance and movement. Activities where music listening is the focus are also scarce. 
Creative work involving music is emphasised in the compulsory comprehensive school curriculum (Kursplan, 2000). One can of course argue that playing covers based on existing music is a creative process, but the artistic aspects of music in terms of creating new music, using sounds for interpretation, composing or improvising have had little impact on the teaching (Thavenius, 2002; Skolverket, 2007). Teachers inform students of opportunities to create their own music and the teaching schedules are flexible enough to allow sufficient time for this. However, few students actually embrace this offer and few teachers apply it. Creating is not a central goal (Georgii-Hemming, 2005, 2006).

Thus, repertoire, content and teaching methods are relatively limited. Reasons given by music teachers for why creating music does not occur include that groups are too large, a lack of time, space, instruments and, chiefly, a lack of computers. Teachers also argue that it is a matter of prioritisation (Skolverket, 2007). These perceived barriers often do not exist in upper secondary school (for students aged 16-19), but studies suggest that lessons are still similar to those of compulsory comprehensive schools (for students aged 7-16). However, the reasons given for why there is often a lack of the inclusion of music from various cultures and music listening are expressed differently. It seems that the primary goal is for every student to be offered the opportunity to discover his/her own musical preferences rather than widening their knowledge about different forms of music and different ways of engaging with music. Teachers speak of music lessons as the students' 'breathing space' in the everyday school environment. The central aspect expressed is that students should be able to experience joy and comfort, that they are shown respect and will be given opportunities to succeed in their attempts. Positive experiences in a comfortable environment are therefore seen as more important than encouraging students to play music from other cultures or to compose their own music (Georgii-Hemming, 2005, 2006).

\section{General principles behind the implementation of informal music pedagogy}

The motives for implementing informal pedagogy in schools often stem from a desire to compensate for limitations in the content or methodology of the formal curriculum (Jeffs \& Smith, 1990). Furthermore, informal music pedagogy may be a way to address some students' lack of engagement with music education in schools.

The idea is that through informal music pedagogy, students will be empowered to influence and control the content, as well as the pace, of their own learning. The students choose the music they want to practise and perform, and it is learnt by listening and aural copying rather than from notation. This form of education takes place through self-directed learning, peer-directed learning and group learning, yet with moderate involvement from the teacher. This is considered to provide the students with a sense of recognition and a greater ownership of their learning experiences. The expectation is also that students gradually will become aware of other music genres outside their own experience. Therefore, informal education aims to offer students opportunities to try out new things, take risks and extend their experiences (Green, 2008).

So far, these objectives mainly concern what is happening in the schools. In the general debate concerning informal learning practices, there are, however, also issues and objectives discussed which go beyond school (Green, 2008). This has also been discussed 
by Wright (2008), who - with reference to Freire (1972) and Folkestad (2006) - argues that through drawing on informal learning and inclusion in music pedagogy, students will have the potential to develop social consciousness. In line with the principles mentioned above, informal music pedagogy has a broader range and scope which stretches further than the classroom situation. It intends to provide students with opportunities to participate in their societies as active citizens, both on a musical and more general level. This is a part of students' life-long learning processes, including a preparation for democratic decision-making. It emphasises the importance of recognising other people's views and opinions respectfully, and equally to be treated with respect from others. If informal music pedagogy in practice will facilitate these aspirations, students have the potential to benefit from personal, musical as well as social development within the frames of compulsory music education.

\section{Opportunities and issues with individualised and informal music pedagogy}

There are significant issues relating to the inclusion of informal practices in school. Experiences from music education in Sweden today raise questions regarding the process of learning, the roles and functions of music and education, as well as the role and function of the teacher in the students' learning processes.

The thoughts and reflections that are currently arising in music education in Sweden can be described as originating from an ambition to acknowledge students' musical interests and experiences. What are the musical, pedagogical and democratic consequences of this? Who and what are included in the reality of this pedagogy? Is this music pedagogical strategy leading to participation, inclusion and emancipation?

Opinions among music pedagogues and music researchers are many and varied, but no one argues that schools ought to re-introduce a curriculum which is entirely teacherdirected or excludes popular culture. Rather, questions arise concerning whether education has become too individualised and informal, and - if this is the case - whether there may be a more useful balance between the informal and formal learning situation; between the everyday and the unfamiliar. Can there be a teaching context that can include children's and young people's life worlds as well as widen them, without becoming normative? (Zackari \& Modigh, 2000; Boman, 2002).

\section{Music education in school and students' motivation}

A highly legitimate motive stated for the use of informal teaching strategies is to increase students' engagement with and motivation for music education in school (Green, 2002, 2008; Folkestad, 2006).

The image of Swedish students' motivation that has emerged through the national evaluation and previous research is partly contradictory. Students enjoy the music subject and appreciate being able to play music in groups (Skolverket, 2004b). Music curricula have increasingly become characterised by current music culture, and - at least parts of - popular music are being integrated into the subject (see above, Karlsson \& Karlsson, 2009). Despite this, it appears that students experience the subject as old-fashioned and 
that it lacks breadth of genres (Skolverket, 2004a). Variations between different schools are large, but it can equally be assumed that variations within the subject in a school are small (Skolverket, 2004b).

\section{The role of the teacher in individualised and informal (music) pedagogy}

Connecting with students' experiences is a difficult task in a time of a multitude of norms, values, symbolic codes, and cultural and social backgrounds. Variations become endless (Giddens, 1991). Many argue that in order to facilitate students' personal development as individuals and nurture them towards responsible citizenship, which are the main aims of schools, supervised and individualised pedagogy appears to be the only solution. Individualisation in terms of individual projects has had a major impact on schools in general. This demands that teachers possess a wide range of knowledge in order for the supervision of projects to be adequate. If there is a lack of knowledge and competence, students risk being left to their own perceptions and experiences (Madsén, 2002).

Madsén (2002) argues that the ideas of 'teachers as supervisors' and students as seekers out of knowledge, leads to teachers simply becoming 'administrators' of students' work. Teaching is not simply about the transmission of information, but also about individuals actively constructing ideas of the world through interaction between the known and the unknown. In order to create new knowledge, an active dialogue - between teacher and student, between student and student - based upon awareness and understanding is required. Teachers must therefore be able to comprehend students' experiences, understanding and thinking in order deliberately to be able to challenge it (Madsén, 2002).

Sociologist and youth researcher, Ove Sernhede (2006) also argues that the necessary abstraction- and reflection processes of knowledge development are being made more complicated if boundaries between school and everyday life become too blurred. Instead, he states that school must be allowed to become a designated space for learning, if it is to be a place where young people feel that their realities are being taken seriously. School must be an arena for vital discussions concerning life where students, teachers and experienced adults meet, discuss and challenge preconceived beliefs, opinions and prejudices. The teacher's task is to make the classroom a platform for democratic discussion and equal participation and to ensure that everyone's voice will be heard, considered and recognised.

In a recently conducted study of student music teachers' perceptions of their ongoing teacher education (Georgii-Hemming \& Westvall, 2010), some criticism emerged of music education in compulsory comprehensive school. Student teachers who participated in the study had, at the time of data collection, undertaken placements in schools on six occasions. As a result of these experiences, student teachers argued that music education in school lacked progression of knowledge. Perceptions of the student teachers were that teachers 'plodded along' without awareness of goals and without considering the curriculum. Instead, what actually happened during the lessons appeared to be influenced by what the teachers 'had always done' and by spontaneous conversations with students (Georgii-Hemming \& Westvall, 2010).

The opinions that music lessons were characterised by temporary solutions and improvised discussions, influenced by makeshift trends and a kind of 'what shall we do 
today?' methodology, have been confirmed in the results from the national evaluation. The evaluation stated that teaching tended to be short-term in character, as well as unplanned and populist (Skolverket, 2004).

As discussed earlier, the curriculum for music education is open as well as non-linear in character. Goals related to social and personal development are emphasised ahead of musical knowledge. This makes local variations possible, which is also one of the aims with the decentralised education system. This article does not allow sufficient space to discuss political and ideological reasons behind this development. However, it is impossible to completely ignore the fact that the character of music is situated and that every educational situation is unique. The scope for local influence and variation can be viewed as positive in a school where the music subject has strong traditions, is a part of the local identity and is an appreciated and integrated part of a wider context (Ericsson, 2002). The fact that teachers and students can select working methods and educational content according to their own situation can increase general satisfaction.

A counter-argument to the above is that development of musical knowledge and skills demands repetition, continuity and practice aligned with a deliberately well-structured material that gradually increases in complexity. An open and non-linear curriculum also results in difficulties with grading and issues with creating a nationally comparable education, which complicates student mobility. A student who wants or has to change school should be able to recognise teaching methods and content, as well as have relevant knowledge in order to participate in the activities (Skolverket, 2007).

\section{Participation and inclusion}

Teaching methods, activities and educational strategies that belong to ideas of informal learning are not only aimed at connecting with students' experiences in everyday life. Participation and inclusion - in and beyond school - are important goals with informal learning (Green, 2008; Wright, 2008).

Previous cultural hierarchies between 'high' and 'low' have, if not entirely dissolved, at least adopted a different shape (Sernhede, 2006). Many music teachers in Sweden are connecting with students' music preferences, leisure-related knowledge and interests (Stålhammar, 2006; Bergman, 2009). The problem is that this mainly appears to benefit those students who play instruments during leisure-time (Skolverket, 2004a, 2004b). The national evaluation has not investigated the instruments, genres or experiential contexts to which this applies. However, experiences from pop- and rock bands were partly useful in school, whereas skills in creating music with the aid of computers or mixing music were not at all reflected in the grading. The national evaluation also stressed that the majority of those who missed computers for music-making were boys from an ethnic background (Skolverket, 2004b).

Thus, an ambition to connect with students is not inclusive of all groups of students (Stålhammar, 2006). These issues have ethnic as well as socio-economic dimensions (Lundberg et al., 2003).

This problematic situation is being confirmed, complicated and amplified in a recent thesis within musicology (Bergman, 2009). In this ethnographic study, a group of youths were studied both in school and during leisure from 2002 to 2005, as they attended 
the Swedish school years 7-9 (aged approximately 13-15). During this period music lessons occurred in uniform gender groups and were based on students forming bands and rehearsing songs. Experiences from informal contexts, e.g. playing in bands, were thus nurtured. However, it is problematic that these experiences were considerably higher valued than skills to play an instrument which did not belong to a traditional rock band setup, e.g. saxophone or violin.

The music teacher in the study aimed toward working in accordance with informal strategies and to connect with student interests. This strategy led to vaguely structured lessons designed by questions along the lines of 'who wants...?' or 'what do you want...?'. The result was that dominant students controlled content and design, and they also had the courage to try out different instruments. Quiet students, on the other hand, remained quiet, and those who did not have experience of playing an instrument did not dare to try either. Differences and problems also increased as the years went on.

In addition to ethnic, socio-economic and social issues, the study also highlights gender-related problems. According to Bergman (2009), boys who did not play electric guitar, bass or drums lost interest and started skipping classes during the last year. The uniform gender groups led to the girls developing a traditionally feminine position during the classes. Although they had a 'go and get it'-kind of attitude in other mixed gender groups in school, they appeared insecure with low self-esteem during the music lessons.

A critical reflection of whom and what is included should contain topics that encompass students with, as well as without, a personal interest in music. It is not necessarily a positive thing that students with a personal engagement in music have their experiences included in the lessons. Music can represent and give rise to identities (Bennett, 2000; Frith, 2002) as well as be a way to explore and visualise life experiences (Ruud, 1996). Music has a strong connection with independence and personal integrity (Ericsson 2002; Stålhammar, 2006). For those young people where certain music is an important and active part of these processes, a teaching strategy connecting closely to students can turn students' private projects into school projects. What was previously private, and perhaps also secluded, could instead become valued as a public qualification (Skolverket, 2004b).

\section{Future music education}

\section{Emancipation and multiculture}

So far, this article has highlighted the conception that informal and individualised strategies do not necessarily result in motivation, participation and inclusion. Music educational issues, closely related to the knowledge development and content of the subject, have concerned misgivings about progression and the concern that areas of music creativity, composition and music listening are not highly prioritised in music education in Sweden.

We have also stressed the fact that decentralisation and an increase in individualisation have resulted in large differences between schools. As a result of a sharp focus on individual students' interests and an openly formulated curriculum - where (music) education is given opportunities to be situated; the context and traditions of the individual school combined with the participants' experiences - it is possible to speak of music education in Sweden in terms of local cultures. 
Sernhede (2006) draws a parallel between this development trend and a general increase in ideas of distinctiveness, as well as what is sometimes referred to as 'tribalisation' (Maffesoli, 1988), which can lead to problems like marginalisation and class segregation. Sernhede argues that it is unfortunate if schools are contributing to a strengthening of these segregating tendencies.

Furthermore, this relates to considerations of the democratic task of schools to develop tolerance and understanding between geographic, ethnic, social and musical cultures; to facilitate meetings between people of different generations, gender and who have different interests. Young people in today's society neither adopt nor grow unreflecting into their parents' life choices, cultures or a particular traditional canon. Meaning and goals must be created and reconstructed by the individual (Sernhede, 2006). If schools succeed in their democratic task they will not only develop responsible, aware and unprejudiced citizens; students will also be able to find alternative and multiple identities, life worlds and choices - which are referred to as emancipation in critical pedagogy (cf. Freire, 1972; Wright, 2008).

Problems surrounding an individually or locally rooted music education connect to the relationship between the local, the global and media's functions in these processes. Media is an important inspiration in young people's identity construction. Media 'teaches' people what values are considered to be important, what lifestyles are possible and desirable. It is sometimes said that young people live in a global music culture, where through media they both encounter and can 'conquer' different genres and cultures (Skolverket, 2004b).

Even though we in this context cannot further examine this complex issue, it is necessary to stress that the cultural multitude and its role models, through globalisation, has actually decreased (Giddens, 1990, 1991; Bauman, 2000, 2001; Lundberg et al., 2003; Smiers, 2003). It is therefore necessary for schools and teacher education to develop a professional awareness concerning issues related to the role that media plays in young people's lives. Undoubtedly, music education needs to address and include popular culture, but it should also contain a critical and sound discussion concerning popular culture and media. In that way, music learning has the potential to contribute to a thriving multitude and will encourage solidarity, acceptance and awareness within the frame of compulsory music education (Georgii-Hemming \& Westvall, 2010).

Undoubtedly, school is a part of the society, as is popular culture. Consequently, schools need to strive towards an understanding of this culture. Students also need to be able to have their own experiences of music - physically, intellectually and emotionally and be given opportunities to understand cultural processes and structures in society, as well as in educational settings (Ruud, 1997). Thus, a central issue is what functions and roles music education as part of compulsory school will and can have in the future.

It may not be productive any more to strive for schools to become more informal and further approach students' everyday lives (Sernhede, 2006). Personal development and construction of meaning both occur through encounters between the known and the unknown (Gadamer, 1960; Ziehe, 1993). Sernhede argues that young people lack confidence in the current school system. Not because of too much alienation, but because schools 'let them do whatever they want' (Sernhede, 2006, p. 15). Instead of deliberately structured and formalised learning, large parts of music education are currently characterised by informal pedagogical strategies. The original development that 
has influenced current Swedish education had democratic ambitions, but Sernhede argues that the resulting practices today do not lead to liberation and emancipation. In order to contribute to young people's identity work, opportunity to construct coherence and meaning, schools need to represent a meeting place where questions can be asked from different perspectives (2006).

\section{Conclusion}

Music is a personal matter in the sense that music is created, perceived and experienced by humans. In schools, there are students with many and various, as well as few, musical experiences. Students have stronger and weaker personal relationships with music, in many different respects. Professional music educators can and must respect, understand and relate to this. Teachers have an ethical, moral and democratic responsibility to help students to construct meaning and develop their social and cultural foundations so they will be prepared to meet, understand and collaborate with other people from a multitude of cultures in the widest sense. If responsibility for music education content and activities is left completely to students, we risk failing students, music and the meaning that music can have for people.

Informal pedagogy can be 'a way ahead' for music education. However, informal learning in schools is a part of formal education and must therefore be supplemented and supported by formal learning. Schools are, and should be, an active arena for democratic processes in the widest sense. For music educators it is an important challenge to reach out and include students in active musicianship within the frames of compulsory music education. Functions and uses of music should no longer mean simply a socialisation into a dominant culture - either lofty or everyday - but should instead contain a dialogue, and an exchange organised, initiated and guided by the teacher. This dialogue between different experiences should be respectful, critical, playful, musical and educational; where musical creativity in different forms could contribute to the development of individuals as well as the development of society. Music education could be an exciting encounter between the familiar and the unfamiliar, between the individual and the collective, and an opportunity for the local and the global to meet. Music education is both a personal as well as a collective matter.

\section{References}

BAUMAN, Z. (2000) Globalization. The Human Consequences. New York: Columbia University Press.

BAUMAN, Z. (2001) The Individualized Society. Cambridge: Polity Press.

BENNETT, A. (2000) Popular Music and Youth Culture: Music, Identity, and Place. Basingstoke: Macmillan.

BERGMAN, Å. (2009) Växa upp med musik: ungdomars musikanvändande i skolan och på fritiden [Growing up with music. Young people's use of music in school and during leisure time]. Diss. Gothenburg: University of Gothenburg. Faculty of Arts.

BOMAN, Y. (2002) Utbildningspolitik i det andra moderna. Om skolans normativa villkor. Diss. Örebro : Örebro universitet.

ELLIOTT, D. (Ed.) (2005) Praxial Music Education: Reflections and Dialogues. New York: Oxford University Press. 
ENGLUND, T. (2005) Läroplanens och skolkunskapens politiska dimension. [Curriculum as a political problem] Göteborg: Daidalos.

ERICSSON, C. (2001) 'Skolans musikverksamhet som offentligt rum: en diskussion av Thomas Ziehe's begrepp i ljuset av en empirisk studie', Nordisk musikkpedagogisk forskning, 5, 63-73.

ERICSSON, C. (2002) Från guidad visning till shopping och förströdd tillägnelse: moderniserade villkor för ungdomars musikaliska lärande. Diss. Lund: Lunds Universitet.

FOLKESTAD, G. (2006) 'Formal and informal learning situations or practices vs formal and informal ways of learning', British Journal of Music Education, 23, 135-145.

FORSBERG, E. (2000) Elevinflytandets många ansikten [The Many Faces of School Student Impact]. Diss. Uppsala: Uppsala University.

FREIRE, P. (1972) Pedagogy of the Oppressed. Harmondsworth: Penguin.

FRITH, S. (2002 [1996]) Performing Rites. On the Value of Popular Music. Cambridge, MA: Harvard University Press.

GADAMER, H.-G. (1997 [1960]) Sanning och metod. I urval. [orig. Wahrheit und Methode. Grundzüge einer philosophischen Hermeneutik]. Göteborg: Daidalos.

GEORGII-HEMMING, E. (2005) Berättelsen under deras fötter: Fem musiklärares livshistorier. [The Story Beneath their feet. Five music teachers' life histories]. Diss. Örebro : Örebro universitet. Accessible on the Internet: http://urn.kb.se/resolve?urn=urn:nbn:se:oru:diva-109

GEORGII-HEMMING, E. (2006) 'Personal experiences and professional strategies', Music Education Research, 8, 217-236.

GEORGII-HEMMING, E. \& WESTVALL, M. (2010) 'Teaching music in our time. A study of student teachers' reflections on participation, inclusion and the right to musical development in their school-based music teacher education', Music Education Research, in press.

GIDDENS, A. (1990) The Consequences of Modernity. Cambridge: Polity in association with Blackwell.

GIDDENS, A. (1991) Modernity and Self-identity. Self and Society in the Late Modern Age. Cambridge: Polity.

GREEN, L. (2002) How Popular Musicians Learn. A Way Ahead for Music Education. Aldershot: Ashgate.

GREEN, L. (2008) Music, Informal Learning and the School. A New Classroom Pedagogy. Aldershot: Ashgate.

JEFFS, T. \& SMITH, M. (Eds.) (1990) Using Informal Education: An Alternative to Casework, Teaching and Control? Milton Keynes: Open University Press.

KARLSSON, C. \& KARLSSON, S. (2009) Lagom svåra och hyfsat moderna. En undersökning av spelrepertoaren i skolår 7-9. ['Not too difficult and quite modern'. A study of repertoire in compulsory music education amongst 13 to 15 -year-old pupils.] Bachelor thesis in Music Education. Örebro: School of Music, Theatre and Art, Örebro University.

Kursplan 2000. Kursplan och betygskriterier i musik för grundskolan. Stockholm: Skolverket. Accessible on the Internet: http://www3.skolverket.se/ki03/front.aspx?

Lgr 62. Läroplan för grundskolan 1962. Allmän del. Skolöverstyrelsens skriftserie 60. Stockholm: SÖ-förlaget. Lgr 69. Läroplan för grundskolan 1969. Allmän del. Stockholm: Liber Utbildningsförlaget.

Lgr 80. Läroplan för grundskolan 1980. Allmän del. Stockholm: Liber Utbildningsförlaget.

LILLIESTAM, L. (1995) Gehörsmusik. Blues, rock och muntlig tradering. Göteborg: Akademiförlaget.

LILLIESTAM, L. (2001) 'En dödsmetall-hardcore-hårdrocksgrej, det är jättesvårt att förklara'. Göteborgska gymnasister tänker och talar om musik. Göteborg: Institutionen för musikvetenskap, Göteborgs Universitet.

Lpo 94. Läroplan för det obligatoriska skolväsendet 1994. Skolverket. Stockholm: Fritzes.

LUNDBERG, D., MALM, K. \& RONSTRÖM, O. (2003) Music, Media, Multiculture: Changing Music Landscapes. Stockholm: Svenskt visarkiv. Accessible on the Internet: http://www.visarkiv.se/mmm/

MADSÉN, T. (2002) 'Återupprätta läraren!', Pedagogiska Magasinet, 3, 54-59.

MAFFESOLI, M. (1988) 'Jeux De Masques. Postmodern Tribalism', Design Issues, IV (1 \& 2, Special Issues). RUUD, E. (1996) Musikk og verdier. Musikkpedagogiske essays. Oslo: Universitetsforlaget. 
RUUD, E. (1997). Musikk og identitet. Oslo: Universitetsforlaget.

SANDBERG, R. (2006) 'Skolan som kulturell mötesplats', in U. P. Lundgren (Ed.), Uttryck, intryck, avtryck. Lärande, estetiska uttrycksformer och forskning (pp. 35-65). Stockholm: Vetenskapsrådet. Accessible on the Internet: http://www.cm.se/webbshop_vr/pdfer/Rapport\%204.2006.pdf

SERNHEDE, O. (2006) 'Skolan och populärkulturen', in U. P. Lundgren (Ed.), Uttryck, intryck, avtryck: Lärande, estetiska uttrycksformer och forskning (pp. 11-19). Stockholm: Vetenskapsrådet. Accessible on the Internet: http://www.cm.se/webbshop_vr/pdfer/Rapport\%204.2006.pdf

SKOLVERKET [Swedish National Agency for Education] (2004a) National Evaluation of the Compulsory School in 2003. A summary main report. Accessible on the Internet: http://www.skolverket.se/ publikationer?id=1404

SKOLVERKET [Swedish National Agency for Education] (2004b) Nationell utvärdering av grundskolan 2003. Bild, hem- och konsumentkunskap, idrott och hälsa, musik och slöjd [National evaluation of the compulsory school in 2003. Subject report]. Accessible on the Internet: http://www.skolverket.se/ publikationer?id=1385

SKOLVERKET [Swedish National Agency for Education] (2005) Grundskolans ämnen i ljuset av Nationella utvärderingen 2003. [Subjects in Compulsory School in the light of the National Evaluation] Accessible on the Internet: http://www.skolverket.se/publikationer?id=1497

SKOLVERKET [Swedish National Agency for Education] (2007) Musik - En samtalsguide om kunskap, arbetssätt och bedömning. Accessible on the Internet: http://www.skolverket.se/publikationer?id=1889

SMIERS, J. (2003) Arts under Pressure: Promoting Cultural Diversity in the Age of Globalization. London: Zed Books.

STÅLHAMMAR, B. (1995) Samspel. Grundskola - musikskola i samverkan: en studie av den pedagogiska och musikaliska interaktionen i en klassrumssituation. [Interplay. School and music school in collaboration: a study of pedagogic and musical interaction in a classroom situation]. Diss. Göteborg: Göteborgs universitet.

STÅLHAMMAR, B. (2006) Musical Identities and Music Education. Aachen: Shaker.

SOU (1948:27) 1946 års skolkommisions betänkande med förslag till riktlinjer för det svenska skolväsendets utveckling.

THAVENIUS, J. (2002) Den goda kulturen och det fria skapandet: Diskurser om 'Kultur i skolan'. Malmö: Malmö högskola, Lärarutbildningen. Accessible on the Internet: http://www.lut.mah.se/ publikationer/utbrapp1302.pdf

VARKØY, Ø. (2001) Musikk for alt (og alle): Om musikksyn i norsk grunnskole. Diss. Oslo: Universitetet i Oslo.

WRIGHT, R. (2008) Thinking Globally, Acting Locally: Informal Learning and Social Justice in Music Education. Music Education as Liberatory Education. Paper presented at the International Society of Music Education, World Conference, Bologna. 20-25 July 2008.

ZACKARI, G. \& MODIGH, F. (2000) Värdegrundsboken. Om samtal för demokrati i skolan. Stockholm: Utbildningsdepartementet, Regeringskansliet. Accessible on the Internet: http://www. regeringen.se/sb/d/108/a/22393

ZIEHE, T. (1993) Kulturanalyser. Ungdom, utbildning, modernitet. Stockholm/Stehag: Symposion. 